V. P. Grakhov, DSc in Economics, Professor, Kalashnikov ISTU

Yu. G. Kislyakova, PhD in Education, Kalashnikov ISTU

Z. S. Saidova, Master's degree student, Kalashnikov ISTU

\title{
THE PLACE OF RUSSIAN STUDENTS IN CROSS-BORDER HIGHER EDUCATION
}

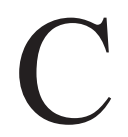

ross-border higher education is now playing a special part in globalizing higher education. It means that a provider, programme, course material, teacher or student moves outside the borders of the country. All over the world universities find themselves operating in an increasingly internationalizing and globalizing environment.

The growing number in internationally mobile students (those who have moved to another countryseeking to participate in educational activities) reflects rising university enrolment all over the world. Last year, more than 4million students went to other countries to study, which is twice more than in 2000 [1].

The largest number of mobile students come from China (more than 712 thousand students), India (more than 181ths), Germany (119ths) and Republic of Korea (117 ths). Total number of mobile students from Russia studying abroad is 50642 .

Travelling students is an old phenomenon and certain regions of the world have a long history of it. Most European countries have been facing the influx of students from their former colonies. Many students from Latin American want to obtain postgraduate degrees in Northern American universities. During of the Cold War, the higher education institutions of the USSR and countries ofEastern Europe attracted students from ideologically associated nations [2].

The largest number of mobile students go to North America and Western Europe (57 \% of total mobile students), East Asia and the Pacific (19\%), Central and Eastern Europe (10\%).

In 2015 , six destination countries hosted nearly $50 \%$ of total mobile students: the United States (19\%), United Kingdom (10\%), Australia (6\%), France (6\%), Germany (5\%) and Russian Federation (3\%). For Russian students the most popular destinations are Germany (9 480 - 19\%), USA (4 688 - 9\%), France (3 643 - $7 \%$ ), UK (3 $604-7 \%$ ) and Czech Republic (3 455 - $7 \%$ ).

Russian Federation as a destination country mostly attracts students from countries that once were a part of the Soviet Union and have common mentality. Total number of mobile students hosted in Russia is 138 496, with the highest number coming from Kazakhstan (35 $106-25 \%)$, Belarus (26 $434-19 \%)$, Azerbaijan (10 $530-8 \%$ ), Uzbekistan (10 $211-7 \%$ ) and Turkmenistan (10 128 - $7 \%$ ) [3].

The benefits of getting a degree in developed countries are obvious and include opportunity to learn new languages, find a well-paid job upon completion and, most importantly, get a high quality education.

Most employers tend to give a job to those who have a high quality education and hand on knowledge re- quired for the job. This is why students from emerging countries are attracted to Western educational institutions that issue diplomas recognized worldwide [4].

Another important characteristic of Western educational institutions is that they offer opportunities to gain relevant experience in the profession during studies. Qualified teachers and professors, advanced equipment, modern school buildings, availability of career counselors, psychologists and personal tutor can make the learning process more effective.

Ability to speak foreign languages is also an important factor that helps build a successful career in the future. While studying abroad, students hone their language skills as they are constantly mingling in an international society. Besides, they practice their reading and writing abilities in the course of their studies. One beneficial opportunity is to establish contacts with potential employers, broaden their horizons, gain access to information in other language.

The benefits of studying abroad also include the opportunity to see new terrains, natural wonders, museums and landmarks of the host nation and the neighboring countries as well! For example, if studying in Hungary, there is an option to travel through various parts of Europe including Vienna, Prague, Zagreb, Buharest and Bratislava.

For students studying in international exchange, teachers in general are more loyal than for their "own", and much more likely to make concessions. The administration of the university is trying to communicate more with foreign students, to engage them in various activities. Comfortable living and school accommodation is a well-known characteristic of Western institutions. Laboratories and lecture halls always have an up-to-date equipment and student residences are often compared with 3 star hotels. The school facilities often have gyms, swimming pools, training equipment, running track, soccer fields, basketball fields and many other venues. There are also many clubs and organizations formed by the school and students that cover many interests and hobbies that students might have. This helps students develop not only towards their future career, but also become better in what they love [5].

Foreign students - a measure of demand, the prestigious university in the world educational space. Therefore, higher education institutions participating in the Bologna process, seek to create favorable conditions for such students. For example, in foreign universities "orientation weeks" for newcomersare traditionally held. A special organization and mentors help foreign students overcome the problems of social adaptation in the new country [6]. 
To make all these possibilities come true, the socalled Sorbonne- and subsequent Bologna-declarations (Joint declaration..., 1998) were issued. Their aimwas to create a common qualifications structure to establish real transparency between existing European systems of higher education through the development of a common basis for understanding these systems and the qualifications they contain. This should improve the recognition of foreign qualifications, enhance the mobility of citizens, make cross-border evaluation more accurate and providea context for effective quality assurance.

The most impressive development in this field has taken place in the European region. Higher Education students have a plenty of mobility opportunities in Europe and beyond: volunteering, jobs, studies, traineeships, or just travelling for fun; just a short stay or a lifechanging year. In Russia, for example, at the beginning of 2014 the "Global Education" programme, that provides financial support to Russian students studying in the world best universities, was launched [7].

In Europe the best known framework of international student mobility is the ERASMUS programme, that offers university students a possibility of studying or doing an internship abroad for a period from 2 months to 12 months per year of studies.

Before going to the host university, the participating student fulfills the Learning Agreement - a document that describes the course of studies. At the end of the stay the host university should issue a document called Transcript of Records which confirms the completed studies' programme and the results. These documents are legally binding for all parties involved (your home and host university). One of the basic rights each exchange student has is the full recognition of courses passed successfully abroad by the home university.

The European Credit Transfer and Accumulation System (ECTS) is a tool of the European Higher Education Area (EHEA) for making studies and courses more transparent and thus helping to enhance the quality of higher education.

Due to its outcome-based approach, the use of ECTS serves many purposes. First of all, it facilitates the recognition of prior learning and experience and encourages a wider participation in lifelong learning. It facilitates mobility within an institution or country, from institution to institution, from country to country, and between different educational sectors and contexts of learning, through recognition and credit transfer. In national legislation the use of ECTS can be a requirement for accreditation of higher education programmes or qualifications.

However, the findings of some theorists merit consideration of a hitherto neglected side effect of the Bologna agreement. An open higher education market in Europe with international student mobility requires funding schemes that allow students to study abroad. Countries that take the lead in facilitating their young people to go abroad may be confronted with a deficit on their human capital trade balance. The possible negative effects of losing young talented individuals should be weighted against possible positive feedback effects such as remittances, creation of business and trade networks, or return migration after the 7-8 years of the working career [8].

Despite the widely acclaimed importance and necessity of active internationalization policies, in our country various factors hinder the development of cross-border exchange programmes.

ECTS is not adopted as the national credit system in Russia, that puts a break on student mobility by hardening the process of recognizing qualifications and periods of study. Students obtaining a degree or a diploma in a foreign country want to get this degree or diploma validated on the labor market in the country where they want to live and work. However, the lack of transparency and "readability" of higher education regulations at national, institutional and sometimes even faculty levels creates all kinds of problems, resulting in a widespread uncertainty among students about the recognition of a credit or the study period in the home university. Non-recognition of study periods abroad causes waste of time for students, extending the overall duration of study and producing extra study load and examinations, etc. Automatic transferability of credits even among countries with a rather similar educational system is still a dream, given that even credit transfer between institutions of the same country usually poses problems.

Some ECTS advocates claim that using credits makes it easier to create and document flexible learning pathways, thus allowing students greater autonomy and responsibility. They say that by using learning outcomes and workload in curriculum design and delivery, ECTS places the student at the center of the educational process. However, Russian students, who are accustomed to a strictly regulated schedule, have difficulties in European universities while independently planning their study program and choosing subjects and areas of interest.

Social adaptation of students in a foreign country is also a hard process. For some of them, this process takes just a few weeks, and for some it lasts for several months or even years. Mentor system is supposed to help foreign students adapt socially. The student benefits from his mentor's support, skills, wisdom and coaching. A mentor is usually a native student, who knows how campus, dormitory, library, cantine and other public places function. An effective mentoring relationships are supposed to develop over time, however, not every mentor is actually willing to help when it comes to real problems.

Among other negative factors one can specify uncertainty of Russian students in their abilities, affordability of staying, concerned with the huge difference in pricing. Expenses on food, clothing and entertainment are usually higher than expected. It is also becoming a significant obstacle to adaptation. For some students government funds can become a life-line.

Besides lack of funding, internationalization also is confronted with lack of explicit and coherent strategies both at the national and the institutional level. All kinds of administrative problems hinder the smooth functioning of internationalization schemes. Students complain because of strict immigration regulations and an overload in bureaucratic paperwork. Worse yet, the visa requirements are constantly changing and even profes- 
sional travel agencies are not willing to help students fill in the applications, get an unconditional offer letter from the chosen university, prove to have funds to cover course fees and living expenses. For example, students, applying for UK student visa, may be asked to hand in bank account statement, with 800 pounds for every day of their stay in the country, which is quite a lot, especially for Russian citizens, considering current exchange rate. Besides, they have to buy a health insurance, hand in lots of different documents, medical analysis, certificates and transcripts, translated in special agencies, etc. As most courses have strict language requirements, students may have to show evidence of their language skills by taking quite difficult language test [9].

Fears and doubts, difficulties of Russian students adaptation abroad are to a large degree the result of the underdevelopment in the international students exchange practices in Russia. The lack of such experience in many Russian universities also causes problems for exchange students. The problem of entering the new sociocultural environment can be solved by strengthening language training and organizing some kind of studies of culture, customs and laws of different countries in Russian higher school when the universities have agreements to carry out exchange programmes with these countries. In this case it is possible for the exchange to become mutually beneficial. It will help to establish strong links with the foreign partners.

Russia's participation in the Bologna process encourages international student mobility, and although Russian students in foreign universities are still more of an exception than the rule, certain steps have been made.
Kalashnikov Izhevsk State Technical University is continuing to strengthen partnerships with foreign universities, particularly with Hungarian, Czech and German ones, that allows to organize various kinds of exchange programmes as well as special training focusing on talented students of different majors.

\section{References}

1. Global Flow of Tertiary-Level Students, UNESCO. URL: http://www.uis.unesco.org/Education/Pages/internationalstudent-flow-viz.aspx, свободный. - Загл. с экрана.

2. Van Damme D. Internationalization and quality assurance : Towards worldwide accreditation? / European Journal for Education Law and Policy. (2000). 4 (1). P. 1-10.

3. Global Flow of Tertiary-Level Students, UNESCO.

4. Rotko A. V. The advantages of education offered abroad // Молодежь. Общество. Современная наука, техника и инновации. - 2013. - № 12. - С. 159.

5. Грахов В. П., Кислякова Ю. Г., Симакова У. Ф. Формирование и развитие творческого потенциала личности студентов технических вузов // Записки горного института. - 2015. - № 213. - С. 110-115.

6. Алашкевич М. Ю., Байденко В. И., Боев О. В. «Мягкий путь» вхождения российских вузов в Болонский процесс. - М. : ОЛМА-ПРЕСС, 2005. - С. 352.

7. Global Education Program. - URL: http://educationglobal.ru/en/, свободный. - Загл. с экрана.

8. Oosterbeek H. Does Studying Abroad Inducea Brain Drain? / Dinand Webbink // Economica. - 2011. - No. 78. Pp. 347-366.

9. Грахов В. П., Кислякова Ю. Г. Из опыта зарубежной стажировки студентов инженерно-строительного факультета ИжГТУ в Техническом университете г. Брно // Образование и наука. - 2015. - № 2(121). - С. 86-93. 